\title{
STRATEGI DEPOT PER DEPOT (DPD) DALAM UPAYA PENINGKATAN PENGETAHUAN DAN PENERAPAN HIGIENE SANITASI DEPOT AIR MINUM ISI ULANG (DAMIU) DI KABUPATEN OGAN ILIR
}

\author{
Inoy Trisnaini ${ }^{1 *}$, Imelda G. Purba² \& Rahmatilah Razak ${ }^{3}$ \\ 1,2,3 Fakultas Kesehatan Masyarakat, Universitas Sriwijaya \\ Jl. Lintas Palembang - Prabumulih, Indralaya, Ogan Ilir, Sumatera Selatan, Indonesia \\ *Korespondensi: inoytrisnaini@gmail.com
}

\begin{abstract}
Abstrak
Berdasarkan Profil Kesehatan Kabupaten Ogan Ilir Tahun 2015, bahwa angka kejadian diare tertinggi pada semua usia dari ialah Kecamatan Indralaya, dengan angka kejadian diare 843 kasus. Mengingat semakin banyaknya penggunaan dan pemanfaatan AMIU untuk kebutuhan vital masyarakat dan adanya indikasi kurang amannya AMIU di berbagai kota besar di Indonesia termasuk di Kabupaten Ogan Ilir, maka perlu adanya pengawasan atau monitor serta pengujian yang memadai atas keamanan AMIU yang beredar di Kabupaten Ogan Ilir. Kegiatan pengabdian dilakukan di 30 Depot Air Minum Isi Ulang (DAMIU) di Kabupaten Ogan Ilir, dengan menggunakan metode penyuluhan secara lisan dan pembagian leaflet. Hasil kegiatan menunjukkan masih terdapat DAMIU yang belum sepenuhnya memiliki sanitasi yang baik, serta masih terdapat karyawan DAMIU yang belum mengetahui dan menerapkan personal hygiene yang baik, sehingga kegiatan pengabdian ini dilakukan dengan harapan dapat meningkatkan pengetahuan dan penerapan hygiene sanitasi Depot Air Minum Isi Ulang di Kabupaten Ogan Ilir. Namun dalam hal ini perlunya kerja sama pihak-pihak terkait, diantaranya ialah dinas kesehatan dan puskesmas setempat.
\end{abstract}

Kata kunci: Depot, air minum, isi ulang, hygiene, sanitasi

\section{PENDAHULUAN}

Berbagai penelitian sebelumnya di berbagai kota besar di Indonesia, menunjukkan AMIU kurang aman serta dapat merugikan kesehatan manusia disebabkan terkontaminasi oleh bakteri (Wandrivel dkk, 2012; Khoeriyah \& Anies, 2015; Wlangitan dkk, 2016; Natalia, 2014; Haryuni dkk, 2014). Penelitian yang dilakukan oleh Institute Pertanian Bogor (IPB) dan Badan Pengawas Obat dan Makanan (BPOM) menyatakan bahwa sebagian besar produk air minum dihasilkan oleh DAMIU dinilai belum memenuhi standar industri air minum dalam kemasan. Penelitian dilakukan dibeberapa kota besar seperti Jakarta, Bandung, Medan serta Surabaya. Hasil 
penelitian di dua lembaga ini menunjukan bahwa air minum isi ulang secara bakteriologis telah terkontaminasi bakteri Coliform, E. Coli, salmonella, sedangkan secara kimiawi sampel air terdeteksi mengandung logam berat kadmium (Rumondor dkk, 2014). Disamping itu penelitian yang dilakukan oleh Putri (2015) di Kecamatan Sebrang Ulu Kota Palembang, menyatakan bahwa 76\% dari produk air minum dihasilkan oleh DAMIU tidak memenuhi syarat kesehatan dan ditemukan bakteri coliform.

Berdasarkan Profil Kesehatan Kabupaten Ogan Ilir Tahun 2015, bahwa angka kejadian diare tertinggi pada semua usia dari tiga kecamatan yaitu Kecamatan Indralaya, Kecamatan Indralaya Utara dan Kecamatan Indralaya Selatan ialah Kecamatan Indralaya, dengan angka kejadian diare 843 kasus. Mengingat semakin banyaknya penggunaan dan pemanfaatan AMIU untuk kebutuhan vital masyarakat dan adanya indikasi kurang amannya AMIU di berbagai kota besar di Indonesia termasuk di Kabupaten Ogan Ilir, maka perlu adanya pengawasan atau monitor serta pengujian yang memadai atas keamanan AMIU yang beredar di Kabupaten Ogan Ilir. Masyarakat juga pada umumnya kurang memberi perhatian dan pertimbangan rasional menyangkut keamanan dan higienitas AMIU karena yang menjadi pertimbangan utama adalah harga yang terjangkau. Hal ini juga didorong oleh kondisi dimana ketersediaan air minum yang bersih dan aman kurang tersedia. Hal ini diperlukan karena masyarakat tidak dapat melihat secara nyata kondisi aman tidaknya AMIU yang dikonsumsi di Kabupaten Ogan Ilir.

Berdasarkan penelitian oleh Trisnaini dkk (2017) pada seluruh Depot Air Minum Isi Ulang di Kabupaten Ogan Ilir yaitu berjumlah 40 DAMIU, didapatkan bahwa hasil pemeriksaan laboratorium ditemukan 13 DAMIU (32,5\%) yang sampel airnya positif mengandung bakteri koliform. Hasil analisis bivariat diperoleh bahwa variabel izin operasi, alat sterilisasi, sumber air baku, ruang pengisian, kebersihan DAMIU, tempat sampah, pemeriksaan bakteriologis, pakaian kerja, pelatihan penajmah makanan, pengawasan berkala, higiene personal, kebersihan diri dan fasilitas cuci tangan tidak memiliki hubungan yang bermakna dengan kualitas bakteriologis air. Penelitian ini menunjukkan bahwa penerapan higiene dan sanitasi Depot Air Minum Isi Ulang (DAMIU) di Kabupaten Ogan Ilir masih tergolong ke dalam kategori buruk. Sehingga perlunya peningkatan pengetahuan dan kesadaran karyawan DAMIU mengenai hygiene sanitasi melalui kegiatan pengabdian masyarakat. Selain itu juga perlu adanya pengawasan dari dinas kesehatan dan memfasilitas pemeriksaan bakteriologis air, dalam hal ini dapat bekerja sama dengan Universitas Sriwijaya sebagai intitusi akademisi di lingkungan terdekat Depot Air Minum Isi Ulang di Kabupaten Ogan Ilir, khususnya dengan memanfaatkan laboratorium yang tersedia di Universitas Sriwijaya. 


\section{METODE PELAKSANAAN}

Kegiatan pengabdian kepada masyarakat ini menggunakan metode survey dan penyuluhan/sosialisasi secara depot per depot yaitu mendatangi di setiap masingmasing depor. Berikut rincian kegiatan yang dilakukan:

a. Memberikan kuesioner kepada 60 orang (pemilik dan pengelola) DAMIU mengenai persyaratan hygiene sanitasi DAMIU.

b. Memberikan penyuluhan / sosialisi secara lisan kepada pemilik dan pengelola DAMIU di Kabupaten Ogan Ilir mengenai persyaratan hygiene sanitasi DAMIU.

c. Memberikan leaflet kepada pemilik dan pengelola DAMIU di Kabupaten Ogan Ilir mengenai persyaratan hygiene sanitasi DAMIU. Berikut leaflet yang digunakan sebagai salah-satu media edukasi pada kegiatan pengabdian ini.

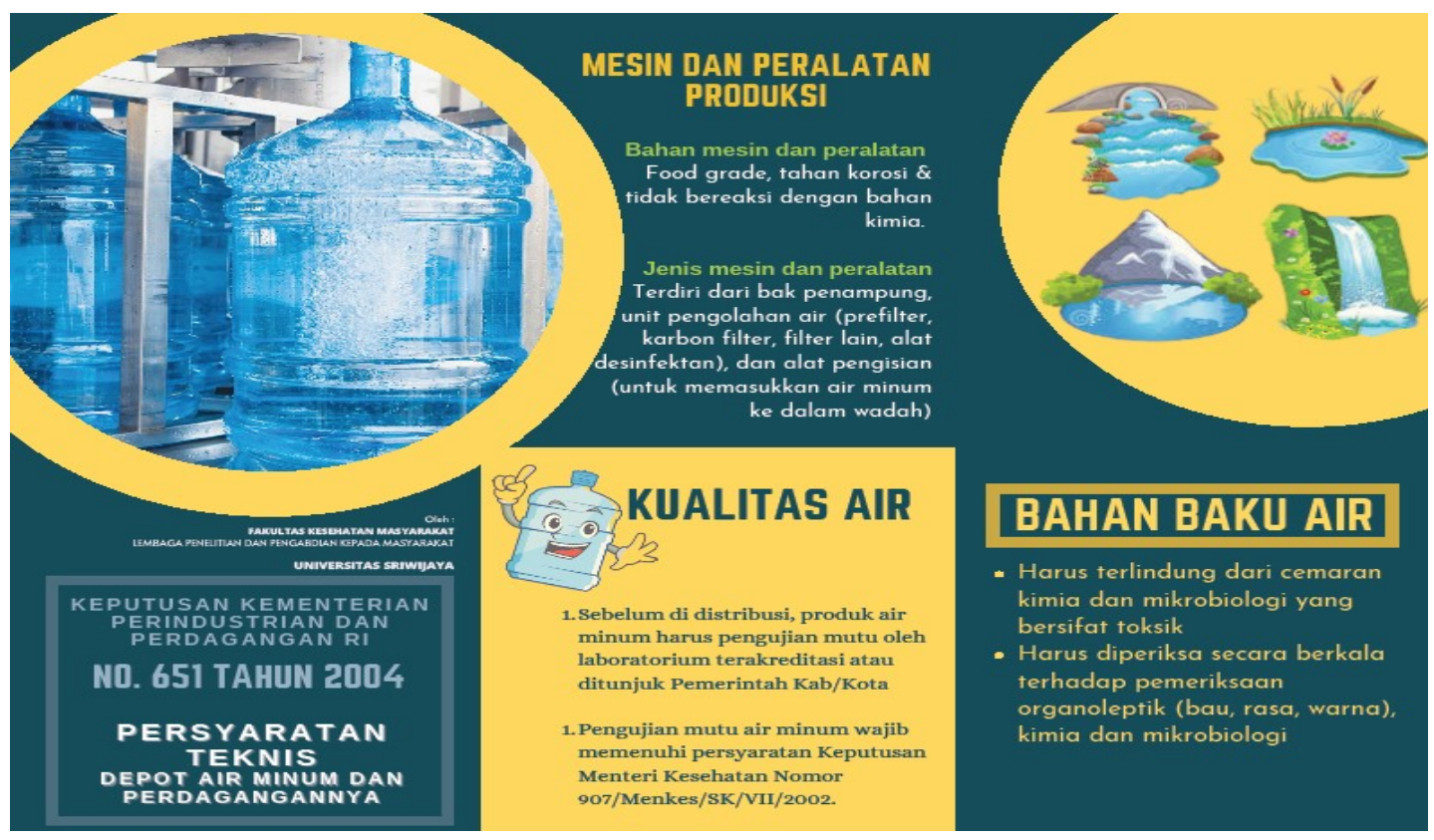

Gambar 1. Pemaparan Materi

Sumber: Dokumentasi tim pengabdian, 2020.

\section{PELAKSANAAN DAN HASIL}

Sasaran pada kegiatan pengabdian ini adalah 30 Depot Air Minum Isi Ulang (DAMIU) di Kabupaten Ogan Ilir., sehingga sasaran pengabdian terdiri dari 1 orang pemilik dan 1 orang pengelola depot yaitu berjumlah 60 orang. Peningkatan aspek kognitif dari 60 orang (pemilik dan pengelola) Depot Air Minum Isi Ulang (DAMIU) di Kabupaten 
Ogan Ilir setelah kunjungan pertama berupa penyuluhan dan sosialisasi mengenai hygiene sanitasi DAMIU.

Penyakit berbasis lingkungan seperti diare merupakan salah satu dari sepuluh penyakit dengan jumlah kasus terbanyak di Kabupaten Ogan Ilir (Dinkes Kab. Ogan Ilir, 2015). Penyebabnya dapat dilihat dari Kesehatan Lingkungan yang kurang memenuhi syarat terutama bagi masyarakat yang belum bisa memenuhi standar hidup bersih dan sehat dilihat dari rendahnya cakupan penduduk dengan akses berkelanjutan terhadap air minum layak. Hasil kegiatan menunjukkan masih terdapat DAMIU yang belum sepenuhnya memiliki sanitasi yang baik, di antaranya ialah untuk aspek pemeriksaan bakteriologis air, kebersihan depot, sarana hygiene sanitasi seperti fasilitas cuci tangan, serta fasilitas tempat sampah, seperti yang terlihat pada tabel berikut ini :

Tabel 1. Higiene Sanitasi DAMIU di Kab. Ogan Ilir

\begin{tabular}{lcc}
\hline Karakteristik & Frequency & Percent (\%) \\
\hline Pemeriksaan Bakteriologis Air & & \\
- Tidak & 15 & 50 \\
- Ya & 15 & 50 \\
Ruang Pengisian Galon & & \\
- Terbuka & 17 & 56.7 \\
- Tertutup & 13 & 43.3 \\
Kebersihan Depot & & 56.7 \\
- Kurang & 17 & 43.3 \\
- Baik & 13 & \\
Kondisi Tempat Sampah & & 60 \\
- Terbuka & 18 & 40 \\
- Tertutup & 12 & \\
\hline
\end{tabular}

Sumber: Hasil Pengabdian, 2020.

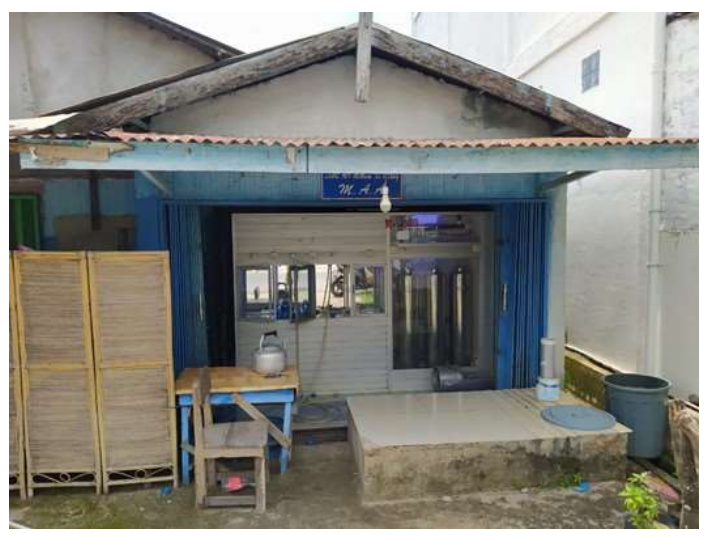

Gambar 2. Tampak Depan Depot Air Minum Isi Ulang (DAMIU)

Sumber: Hasil Pengabdian, 2020. 


\section{Tabel 2. Fasilitas Cuci Tangan DAMIU di Kabupaten Ogan Ilir}

\begin{tabular}{lcc}
\hline Karakteristik & Frequency & Percent (\%) \\
\hline Ketersediaan tempat cuci tangan & & \\
- Tersedia & 28 & 93.3 \\
- Tidak tersedia & 2 & 6.7 \\
Ketersediaan Sabun dan Lap tangan & & \\
- Tersedia & 12 & 40 \\
- Tidak tersedia & 18 & 60 \\
Ketersediaan Air mengalir yang cukup & & \\
- Tersedia & 26 & 86.7 \\
- Tidak tersedia & 4 & 13.3 \\
\hline
\end{tabular}

Sumber: Hasil Pengabdian, 2020.

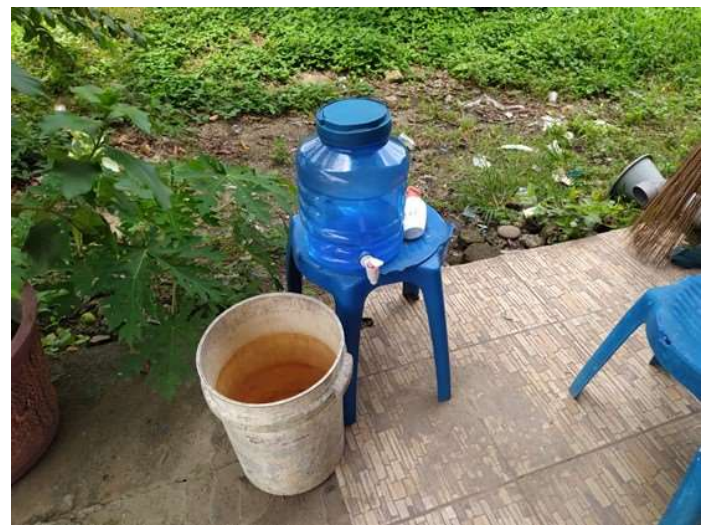

Gambar 3. Fasilitas Cuci Tangan di Depot Air Minum Isi Ulang (DAMIU)

Sumber: Hasil Pengabdian, 2020.

Begitu pula kondisi yang ada mengenai personal hygiene karyawan, hasil kegiatan menunjukkan masih terdapat karyawan DAMIU yang belum sepenuhnya menerapkan personal higiene yang baik, diantaranya ialah untuk aspek perilaku mencuci tanga pakai sabun, kebiasaan merokok, dan kebersihan badan (lihat tabel 3).

Tabel 3. Personal Higiene Karyawan DAMIU di Kabupaten Ogan Ilir

\begin{tabular}{lcc}
\hline Karakteristik & Frequency & Percent (\%) \\
\hline Mencuci tangan sebelum bekerja & & \\
- Ya & 27 & 90 \\
- Tidak & 3 & 10 \\
Mencuci tangan dengan sabun dan air mengalir & & \\
- Ya & 28 & 93.3 \\
- Tidak & 2 & 6.7 \\
Kebiasaan merokok pada saat bekerja & & \\
- Tidak merokok & 5 & 83.3 \\
- Merokok & 25 & 16.7 \\
Kerapihan dan Kebersihan Badan & & \\
\hline
\end{tabular}




\begin{tabular}{llcc}
\hline - & Ya & 26 & 86.7 \\
- & Tidak & 4 & 13.3 \\
\hline
\end{tabular}

Sumber: Hasil Pengabdian, 2020.

Maka untuk meningkatkan penerapan hygiene sanitasi DAMIU serta meningkatkan pengetahuan dan penerapan personal hygiene karyawan dalam pengelolaan air minum isi ulang, maka dilakukan kegiatan pengabdian ini. Kegiatan pengabdian dilakukan dengan menggunakan media penyuluhan secara lisan dan menggunakan leaflet. Kegiatan penyuluhan dilakukan dengan metode mendatangi secara langsung depot per depot air minum isi ulang bukan, metode ini dipilih sebab mengingat dalam kondisi pandemi, sehingga menghindari kegiatan mengumpulkan peserta yang berisiko menimbulkan adanya aktivitas berkumpul/ berkerumun. Berikut dokumentasi dari pelaksaan observasi dan penyuluhan.
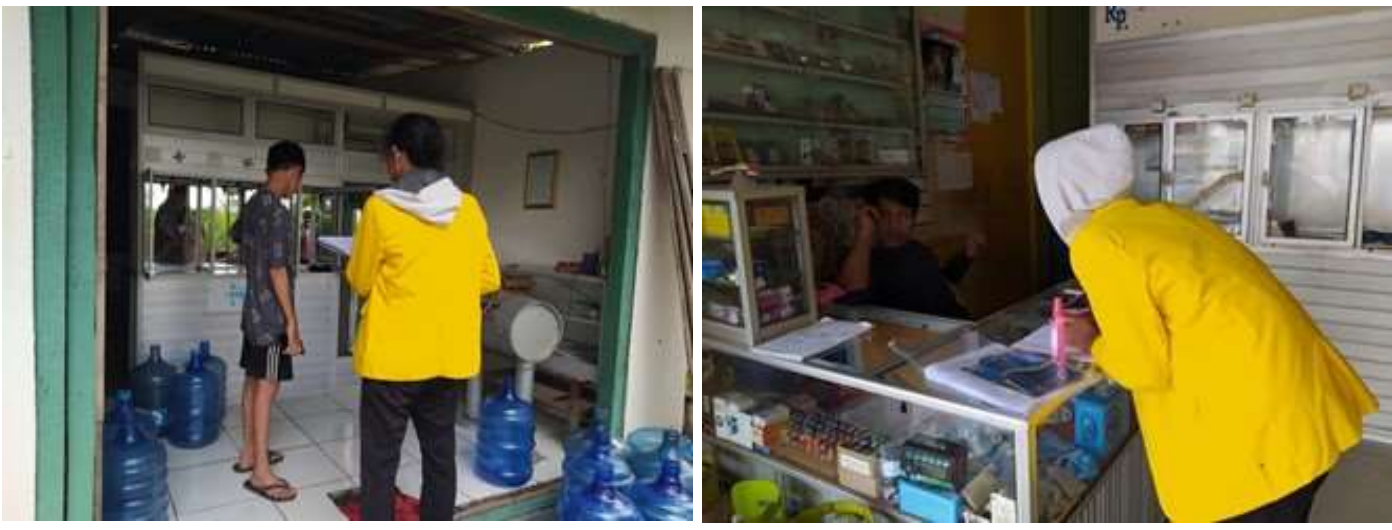

Gambar 4. Pelaksanaan Penyuluhan Hygiene Sanitasi DAMIU

Sumber: Hasil Pengabdian, 2020.

\section{PENUTUP}

Kegiatan pengabdian masyarakat peningkatan pengetahuan pemilik dan karyawan Depot Air Minum Isi Ulang (DAMIU) di Kabupaten Ogan Ilir ini telah terlaksana dengan sasaran 30 pemilik/karyawan Depot Air Minum Isi Ulang (DAMIU). Adapun hasil yang diperoleh dari kegiatan ini ialah meningkatkan pengetahuan pemilik dan karyawan Depot Air Minum Isi Ulang (DAMIU) di Kabupaten Ogan Ilir mengenai hygiene sanitasi DAMIU. Ke depan diharapkan adanya kerja sama dengan pemerintah setempat yang berwenang, dalam hal ini ialah dinas kesehatan dan puskesmas setempat, agar kegiatan penyuluhan dalam dilakukan secara rutin bersamaan dengan pelaksanaan pengawasan berkala, selain itu perlu adanya kerja sama dan bantuan dalam pemeriksaan sampel air baku yang digunakan sesuai dengan Peraturan Menteri Kesehatan RI No. 492/Menkes/Per/IV/2010 mengenai persyaratan 
air minum, untuk menjamin terjaganya air minum isi ulang dari risiko berbagai kontaminasi.

\section{UCAPAN TERIMA KASIH}

Tersusunnya artikel ini tidak terlepas dari dukungan berbagai pihak, oleh karenanya menjadi etika akademik untuk mengahaturkan terima kasih kepada para pihak yang telah mendukung terlaksananya kegiatan pengabdian masyarakat sebagai basis dari artikel ini. Terima kasih kepada dinas kesehatan Kabupaten Ogan Ilir yang telah mengizinkan pelaksanaan kegiatan pengabdian ini.

\section{DAFTAR PUSTAKA}

Dinas Kesehatan Kabupaten Ogan Ilir. (2016). Profil Dinasi Kesehatan Kabupaten Ogan Ilir Tahun 2016.

Haryuni, D. \& Djaja, I. M. (2014). Analisis Kualitas Bakteriologis Air Minum Isi Ulang di Wilayah Kecamatan Cengkareng Jakarta Barat Tahun 2009. Depok: Departemen Kesehatan Lingkungan Fakultas Kesehatan Masyarakat Universitas Indonesia.

Khoeriyah, A. \& Anies (September 2015). Aspek Kualitas Bakteriologis Depot Air Minum Isi Ulang (DAMIU) di Kabupaten Bandung Barat. MKB, 47(3).

Natalia, L. A. (2014). Kajian Kualitas Bakteriologis Air Minum Isi Ulang Di Kabupaten Blora Melalui Metode Most Probable Number. Semarang: Jurusan Biologi Fakultas Matematika dan Ilmu Pengetahuan Alam Universitas Negeri Semarang.

Permenkes Nomor 492/Menkes/Per/IV/2010 tentang Persyaratan Kualitas Air Minum. Jakarta.

Putri, E. M. D. (2015). Hubungan Higiene Sanitasi dengan Kontaminasi Bakteri Coliform Pada Air Minum Isi Ulang di Kecamatan Seberang Ulu 1 Kota Palembang Tahun 2015. Jakarta: Fakultas Kedokteran dan Ilmu Kesehatan Universitas Islam Negeri Syarif Hidayatullah Jakarta

Trisnaini, I., Sunarsih, E., \& Septiawati, D. (2018). Analisis faktor risiko kualitas bakteriologis air minum isi ulang Di Kabupaten Ogan Ilir. Jurnal Ilmu Kesehatan Masyarakat, 9 (1), 28-40.

Rumondor, P. P., Porotu, J., \& Waworuntu, O. (Juli 2014). Identifikasi Bakteri Pada Depot Air Minum Isi Ulang Di Kota Manado. Jurnal e-Biomedik (eBM) 2( 2).

Walangitan, M. R, Sapulete, M., Pangemanan, J. (Februari 2016). Gambaran Kualitas Air Minum Dari Depot Air Minum Isi Ulang Di Kelurahan Ranotana-Weru Dan Kelurahan Karombasan Selatan Menurut Parameter Mikrobiologi. Jurnal Kedokteran Komunitas dan Tropik, IV(7).

Wandrivel, R., Suharti, N., Lestari, Y. (2012). Kualitas Air Minum yang Diproduksi Depot Air Minum Isi Ulang di Kecamatan Bungus Padang Berdasarkan Persyaratan Mikrobiologi. Jurnal Kesehatan Andalas, 1(3). 
